\title{
Benzyladenine Treatment Significantly Increases the Seed Yield of the Biofuel Plant Jatropha curcas
}

\author{
Bang-Zhen Pan · Zeng-Fu Xu
}

Received: 18 June 2010/Accepted: 7 September 2010/Published online: 10 October 2010

(C) The Author(s) 2010. This article is published with open access at Springerlink.com

\begin{abstract}
Jatropha curcas, a monoecious perennial biofuel shrub belonging to the family Euphorbiaceae, has few female flowers, which is one of the most important reasons for its poor seed yield. This study was undertaken to determine the effects of the plant growth regulator 6-benzyladenine (BA) on floral development and floral sex determination of $J$. curcas. Exogenous application of BA significantly increased the total number of flowers per inflorescence, reaching a 3.6-fold increase (from 215 to 784 ) at $160 \mathrm{mg} / \mathrm{l}$ of BA. Furthermore, BA treatments induced bisexual flowers, which were not found in control inflorescences, and a substantial increase in the femaleto-male flower ratio. Consequently, a 4.5 -fold increase in fruit number and a 3.3-fold increase in final seed yield were observed in inflorescences treated with $160 \mathrm{mg} / \mathrm{L}$ of BA, which resulted from the greater number of female flowers and the newly induced bisexual flowers in BA-treated inflorescences. This study indicates that the seed yield of $J$. curcas can be increased by manipulation of floral development and floral sex expression.
\end{abstract}

Keywords 6-Benzyladenine - Bisexual - Cytokinin . Female flowers $\cdot$ Physic nut $\cdot$ Sex determination

B.-Z. Pan - Z.-F. Xu ( $ه)$

Laboratory of Molecular Breeding of Energy Plants,

Xishuangbanna Tropical Botanical Garden, Chinese Academy of Sciences, 88 Xuefu Road, Kunming 650223, Yunnan, China e-mail: zfxu@xtbg.ac.cn; zengfu.xu@gmail.com

B.-Z. Pan

Graduate School of the Chinese Academy of Sciences, Beijing 100049, China

\section{Introduction}

Jatropha curcas (hereafter refer as Jatropha) is a perennial deciduous shrub belonging to the family Euphorbiaceae, which probably originated in Central America and is widely distributed in the tropics and subtropics (Fairless 2007; Carels 2009; Makkar and Becker 2009). Jatropha seed content is about $30-40 \%$ oil, which is an ideal feedstock for producing biodiesel (Kandpal and Madan 1995; Fairless 2007; Jongschaap and others 2007; Sunil and others 2008). At present, however, seed yield of Jatropha is poor and insufficient for the biodiesel industry (Sanderson 2009; Divakara and others 2010).

As a cross-pollinated shrub, Jatropha is monoecious and produces male and female flowers in the same inflorescence (Heller 1996; Liu and others 2008). Normally, female flowers initiate at the center of inflorescences and are surrounded by a group of male flowers (Jongschaap and others 2007). Occasionally bisexual (hermaphrodite) flowers occur (Dehgan and Webster 1979). Each Jatropha inflorescence is composed of 100-300 flowers and yields approximately 10 or more ovoid fruits (Kumar and Sharma 2008; Rao and others 2008; and this study). One of the most likely reasons for poor yield is that Jatropha has few female flowers resulting from a very low female-to-male flower ratio, which, depending on the genotype, is about 1:29-1:13 (Raju and Ezradanam 2002; Tewari and others 2007). Thus, increasing the number of female flowers seems critical for the improvement of Jatropha seed yield.

Studies of exogenous applications of various plant growth regulators (PGRs) and analysis of endogenous phytohormones showed that PGRs play important roles in floral development (Krizek and Fletcher 2005; Irish 2009; Santner and others 2009). Exogenous cytokinin (CK) application has been shown to increase inflorescence 
meristem activity and promote floral initiation in several species (Wang and Li 2008; Werner and Schmulling 2009; Kiba and Sakakibara 2010). Srinivasan and Mullins (1978, 1979) reported that the tendrils of grape (Vitis vinifera) were converted into inflorescences by application of various CKs. Ohkawa (1979) found that 6-benzyladenine (BA, a synthetic compound with $\mathrm{CK}$ activity) treatment had a significant influence on increasing flower numbers of Lilium speciosum, particularly when combined with gibberellins $A_{4}$ and $A_{7}\left(G_{4}+{ }_{7}\right)$. Chen (1991) showed that flower bud differentiation of lychee (Litchi chinensis) was significantly promoted by exogenous kinetin application after bud dormancy. The total number of flowers on jojoba (Simmondsia chinensis) was also significantly increased by treatment with BA (Ravetta and Palzkill 1992; Prat and others 2008). Recently, Li and others (2010) reported that the flower-specific elevation of cytokinin through transgenic expression of an Arabidopsis cytokinin biosynthesis enzyme gene (ATP/ADP isopentenyltransferase 4, AtIPT4) under the control of the APETALAl (APl) promoter led to a threefold increase of flowers in the transgenic plants.

PGRs are also important regulators of floral sex determination, which depends on the plant species (Khryanin 2002, 2007; Xiong and others 2009). CK has been shown to have a feminizing effect on a number of plant species (Khryanin 2002, 2007). For example, CK induced bisexual (hermaphroditic) flowers of grape (Vitis vinifera) (Negi and Olmo 1966, 1972) and also female flowers of Luffa acutangula (Bose and Nitsch 1970) and Luffa cylindrical (Takahashi and others 1980).

To find ways to increase the total number and/or the proportion of female flowers of Jatropha, which may result in increased seed yield, we investigated the effects of exogenous applications of 6-benzyladenine (BA) on the flower, fruit, and seed development of Jatropha.

\section{Materials and Methods}

\section{Plant Materials and Growth Conditions}

One-year-old plants of Jatropha curcas L. were grown in a field with normal fertilization at the Xishuangbanna Tropical Botanical Garden (XTBG, 21 $54^{\prime} \mathrm{N}, 101^{\circ} 46^{\prime} \mathrm{E}$, $580 \mathrm{~m}$ in altitude) of the Chinese Academy of Sciences located in Mengla County, Yunnan Province, southwest China. Plants were monocultured at a density of $2.5 \times 2.5 \mathrm{~m}$. The annual rainfall, temperature, and relative humidity records at the XTBG were $1493 \mathrm{~mm}$, $21.8^{\circ} \mathrm{C}$ and $85 \%$, respectively. The experiments were carried out from April (when the plants were 1 year old) to November 2009.
6-Benzyladenine (BA) Application

A stock solution $(25 \mathrm{mg} / \mathrm{ml})$ of 6-benzyladenine (BA, Bio Basic Inc., Toronto, Ontario, Canada) was prepared by dissolving $1 \mathrm{~g}$ of $\mathrm{BA}$ in $5 \mathrm{ml}$ of $1 \mathrm{~N} \mathrm{NaOH}$ and bringing the final volume to $40 \mathrm{ml}$ with distilled water. Tween-20 (Polysorbate-20, Shanghai Sangon Biological Engineering Technology \& Services Co., Ltd., China) was added at the final concentration of $0.05 \%(\mathrm{v} / \mathrm{v})$ as a wetting agent to all BA working solutions. Five milliliters of BA working solutions of various concentrations $(80,160$, and $320 \mathrm{mg} / \mathrm{l})$ were sprayed on each inflorescence (about $0.5 \mathrm{~cm}$ in diameter) and on surrounding leaves using a hand sprayer. Control inflorescences were sprayed with $5 \mathrm{ml}$ of distilled water containing $0.05 \%(\mathrm{v} / \mathrm{v})$ Tween-20. Spraying was consecutively conducted three times at 1-day intervals. Thirty inflorescences from 10 plants were used for each treatment.

The total number and number of each sex of flowers per inflorescence, fruits per inflorescence, and seeds per fruit were counted. A female flower was defined as a flower with pistils only, a male flower was defined as a flower with stamens only, bisexual flowers were defined as flowers with both pistils and stamens, and an asexual flower was defined as a flower with neither pistils nor stamens. The fruiting rate $(\%)$ was calculated as the number of fruits divided by the number of female and bisexual flowers.

\section{Characterization of Seeds}

After being air-dried for 2 months, weight, size, and oil content of seeds from control and BA-treated plants were measured. Seed oil contents were determined by the minispec mq-one Seed Analyzer (Bruker Optik GmbH, Germany). A calibration curve was obtained from reference samples of oil extracted from Jatropha seeds.

\section{Statistical Analysis}

Data were analyzed using the Statistical Product and Service Solution version 16.0 software (SPSS Inc, Chicago, IL). Differences among means were determined by oneway ANOVA with Tukey's or Tamhane's post hoc tests. Graphics were generated using SigmaPlot version 10.0) (Systat Software, Inc., Point Richmond, CA).

\section{Results}

Effects of BA on Jatropha Flower Development

BA treatment significantly increased the total number of flowers per inflorescence compared to the control (Fig. 1a, 
Fig. 1 Effects of BA treatments on flower development and sex expression of Jatropha. a Inflorescence from control plants. b Inflorescence from BA-treated plants. c-f Flowers of different sexual types from BA-treated plants. c Male flower. d Female flower. e Induced bisexual flower. f Induced asexual flower
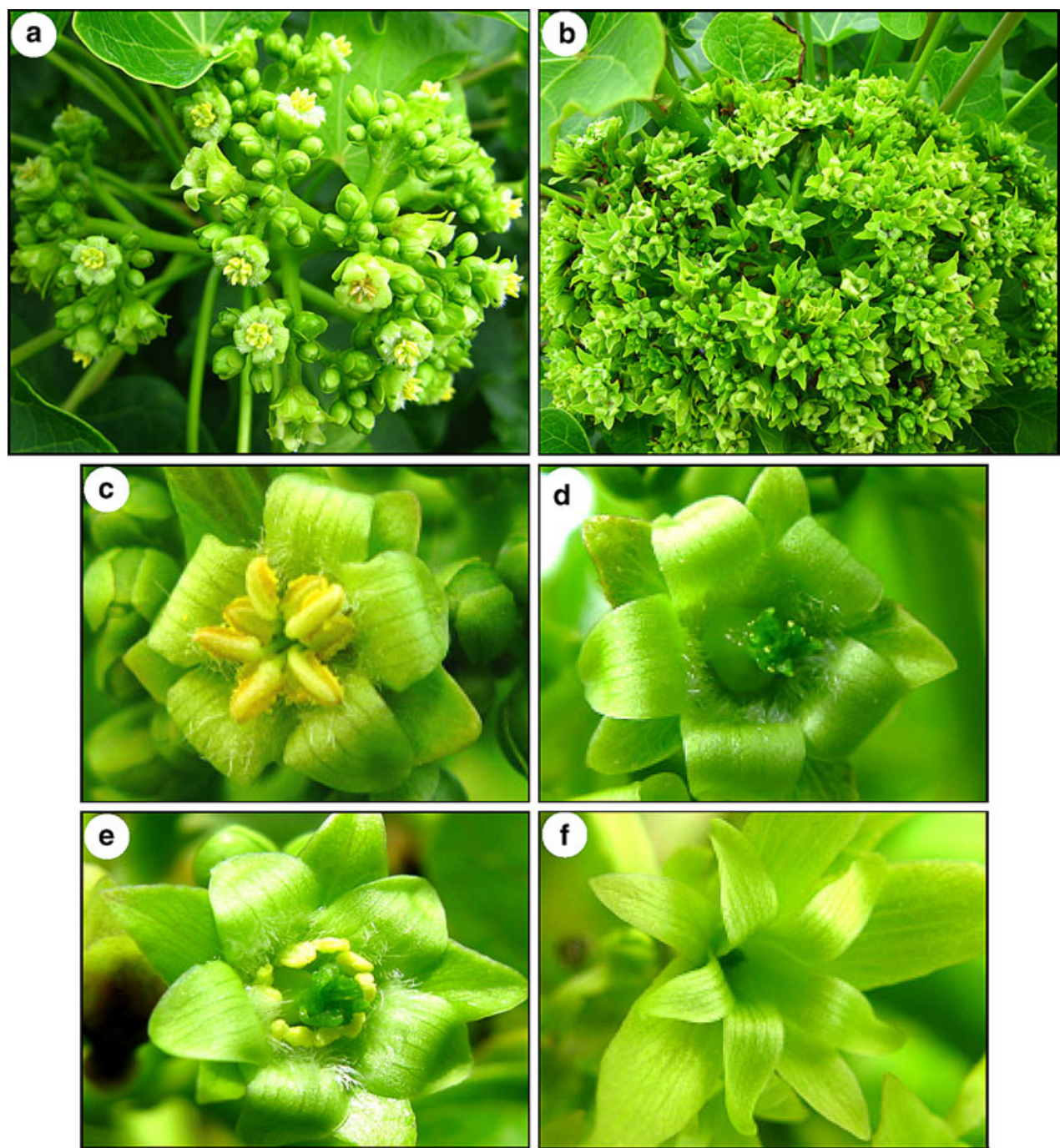

b, 2a). BA treatment at $160 \mathrm{mg} / \mathrm{l}$ resulted in a 3.6-fold increase (from 215 to 784) in flowers per inflorescence (Fig. 2a). We found that in addition to the normal male and female flowers found in control inflorescences (Fig. 1c, d), bisexual and asexual flowers were induced in BA-treated inflorescences (Fig. 1e, f). The number and percentage of flowers of different sex types of Jatropha treated with various concentrations of BA are shown in Fig. 2. Up to $3.09 \%$ of flowers in inflorescences treated with $320 \mathrm{mg} / \mathrm{l}$ of BA were bisexual flowers (Fig. 2b), which were not found in control inflorescences.

Furthermore, interestingly, BA treatments induced a substantial increase in the total number and the proportion of female flowers (Fig. 2). The percentage of female flowers was proportional to the concentration of BA treatment. Female flowers accounted for $29.99 \%$ of total flowers in inflorescences treated with $320 \mathrm{mg} / \mathrm{l}$ of BA, but only for $6.96 \%$ in control inflorescences (Fig. 2b). The female:male ratio was increased from 1:13.4 in control inflorescence to 1:2.4 in inflorescence treated with $320 \mathrm{mg} / \mathrm{l}$ of BA (Table 1), resulting in a 4.3-fold increase in percentage of female flowers. The inflorescences treated with $160 \mathrm{mg} / \mathrm{l}$ of BA produced the greatest numbers of total flowers (784) and female flowers (156), in contrast to the control inflorescences in which only 15 female flowers were found among a total of 215 flowers (Fig. 2a).

\section{Effects of BA on Fruiting and Seed Development}

As expected, many more female flowers and newly induced bisexual flowers in BA-treated inflorescences produced more fruits than the control inflorescences (Fig. 3a, b). In comparison with the control inflorescences, a 4.5-fold increase in fruit number (from 13 to 58 per inflorescence) was observed in inflorescences treated with $160 \mathrm{mg} / \mathrm{l}$ of BA (Fig. 3c, Table 2). The fruiting rates, however, were decreased in all inflorescences treated with $80-320 \mathrm{mg} / \mathrm{l}$ of BA (Fig. 3c). Linear regression analysis revealed a significantly negative correlation between fruiting rate and the number of female and bisexual flowers per inflorescence on 

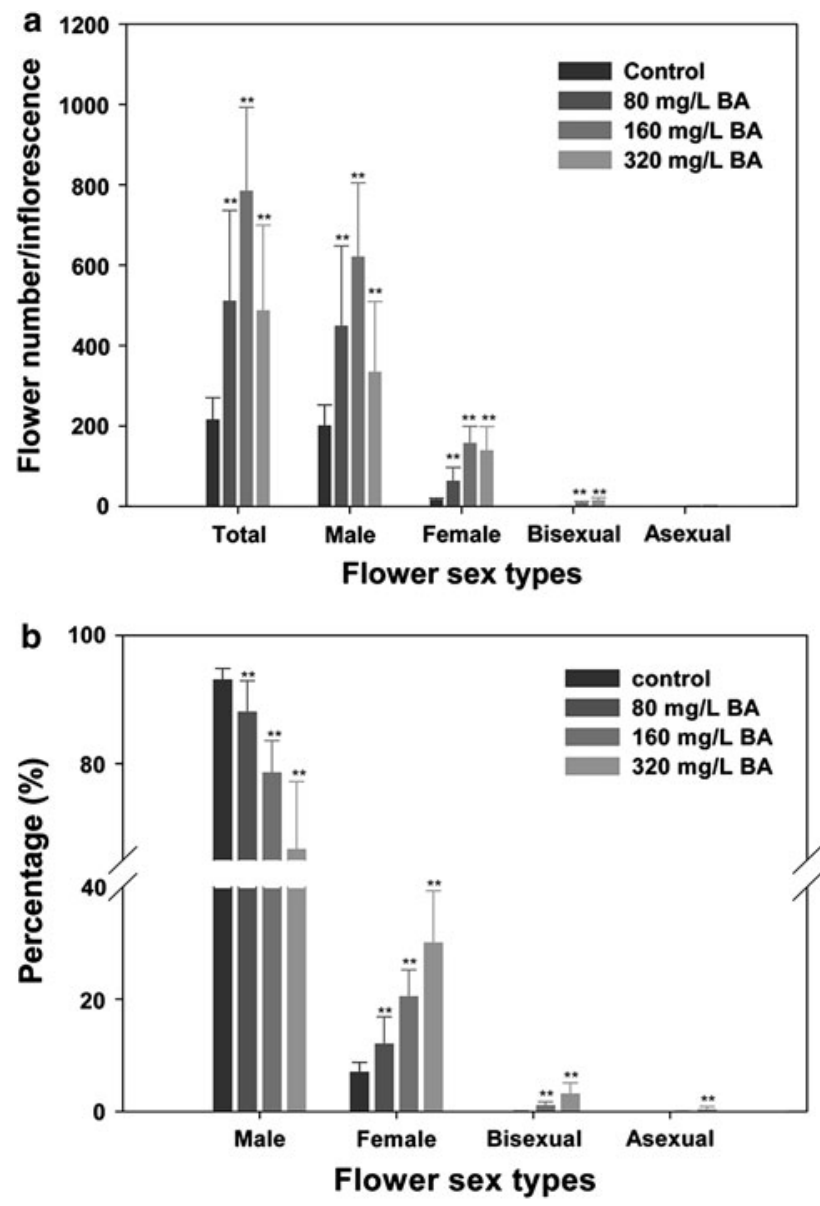

Fig. 2 a Effects of BA treatments on flower number of different sex types per inflorescence. $\mathbf{b}$ Effects of BA treatments on percentage of flowers of different sex types. Values are means \pm standard deviations $(n=30$ inflorescences). $* *$ Statistically significant at the $1 \%$ level

Table 1 Effects of BA treatments on flower number and sex ratio in Jatropha

\begin{tabular}{lcll}
\hline BA treatments & Female & Male & F:M ratio \\
\hline Control & $14.96 \pm 4.96$ & $200.11 \pm 51.92$ & $1: 13.4$ \\
$80 \mathrm{mg} / 1$ & $62.26 \pm 34.41^{*}$ & $448.04 \pm 199.84^{*}$ & $1: 7.2$ \\
$160 \mathrm{mg} / \mathrm{l}$ & $156.00 \pm 43.10^{*}$ & $620.07 \pm 184.66^{*}$ & $1: 4.0$ \\
$320 \mathrm{mg} / \mathrm{l}$ & $138.16 \pm 60.56^{*}$ & $333.24 \pm 176.34^{*}$ & $1: 2.4$ \\
\hline
\end{tabular}

Values are mean \pm standard deviation ( $n=30$ inflorescences)

* Statistically different from the control at $1 \%$ level

plants treated with BA but not in control plants (Fig. 4), which may be a result of either the limited space in the inflorescence or the shortage of photosynthesis products (Gifford and Evans 1981; Sutherland 1986).

Although a low percentage of fruits contain one to two seeds, we found that most Jatropha fruit contains three seeds (Fig. 5a), in agreement with the fact that Jatropha female flowers usually have a three-locular ovary (Heller
1996; Divakara and others 2010). It is rare to find four-seed fruits in our experimental site under normal growth conditions, although they have been observed in some Mexican genotypes (Makkar and others 2008; Makkar and Becker 2009). The BA-treated inflorescences, however, produced four-seed fruits (Fig. 5b), and the number of four-seed fruits increased with the concentration of BA from 80 to $320 \mathrm{mg} / \mathrm{l}$, reaching $2.0 \%$ of total fruits at $320 \mathrm{mg} / \mathrm{l}$ (data not shown). Because more one-seed and two-seed fruits were found in BA-treated inflorescences than in the controls, the average seed number per fruit in the BA-treated inflorescences was slightly, but not statistically significantly, less than that of control inflorescences (Table 2).

Although BA treatment produced many more flowers and fruits, seeds from the BA-treated fruits were slightly lighter (Table 2) and smaller (Table 3) than those from control fruits. The final seed yield per inflorescence was increased by 1.8 -fold (BA at $80 \mathrm{mg} / \mathrm{l}$ ) up to 3.3 -fold (BA at $160 \mathrm{mg} / \mathrm{l})$ (Table 2). Unexpectedly, the oil content of the seeds significantly increased from $31.7 \%$ (control seeds) to $34.8 \%$ (BA-treated at $160 \mathrm{mg} / \mathrm{l}$ ) (Table 2).

\section{Discussion}

Floral development and floral sex determination are critical for optimizing seed yields of monoecious plants. Our data presented in this article clearly show that exogenous application of BA significantly promotes floral development and feminizing effects in Jatropha. BA treatment significantly increased seed yield per inflorescence of Jatropha by increasing the total number of flowers and the proportion of female flowers and the induction of bisexual flowers.

Accumulating evidence suggests that the BA-induced increase in the number of flowers may result from the positive role of cytokinin in the regulation of inflorescence meristem activity and size (Werner and Schmulling 2009; Kiba and Sakakibara 2010). Werner and others (2001, 2003) found that CK-deficient transgenic tobacco and Arabidopsis plants overexpressing Arabidopsis CK oxidase/dehydrogenase (AtCKX, an enzyme-degrading CK) genes developed a reduced number of flowers on each single inflorescence. Consistently, Ashikari and others (2005) found that a quantitative trait locus (QTL) controlling grain number in rice, Gnla, is a gene for CK oxidase/dehydrogenase (OsCKX2). Reduced expression of $O s C K X 2$ resulted from natural mutations or antisense inhibition of $O s C K X 2$, caused CK accumulation in inflorescence meristems, and increased grain number per plant, whereas transgenic plants overexpressing OsCKX2 showed reduced grain numbers compared to control plants 
Fig. 3 a Infructescence from control plants. b Infructescence from BA-treated plants.

c Effects of BA treatments on fruit number per infructescence and fruiting rate. Values are means \pm standard deviations $(n=30$ infructescence). Fruit number and fruiting rate of all treatments were statistically different from the control at the $1 \%$ level
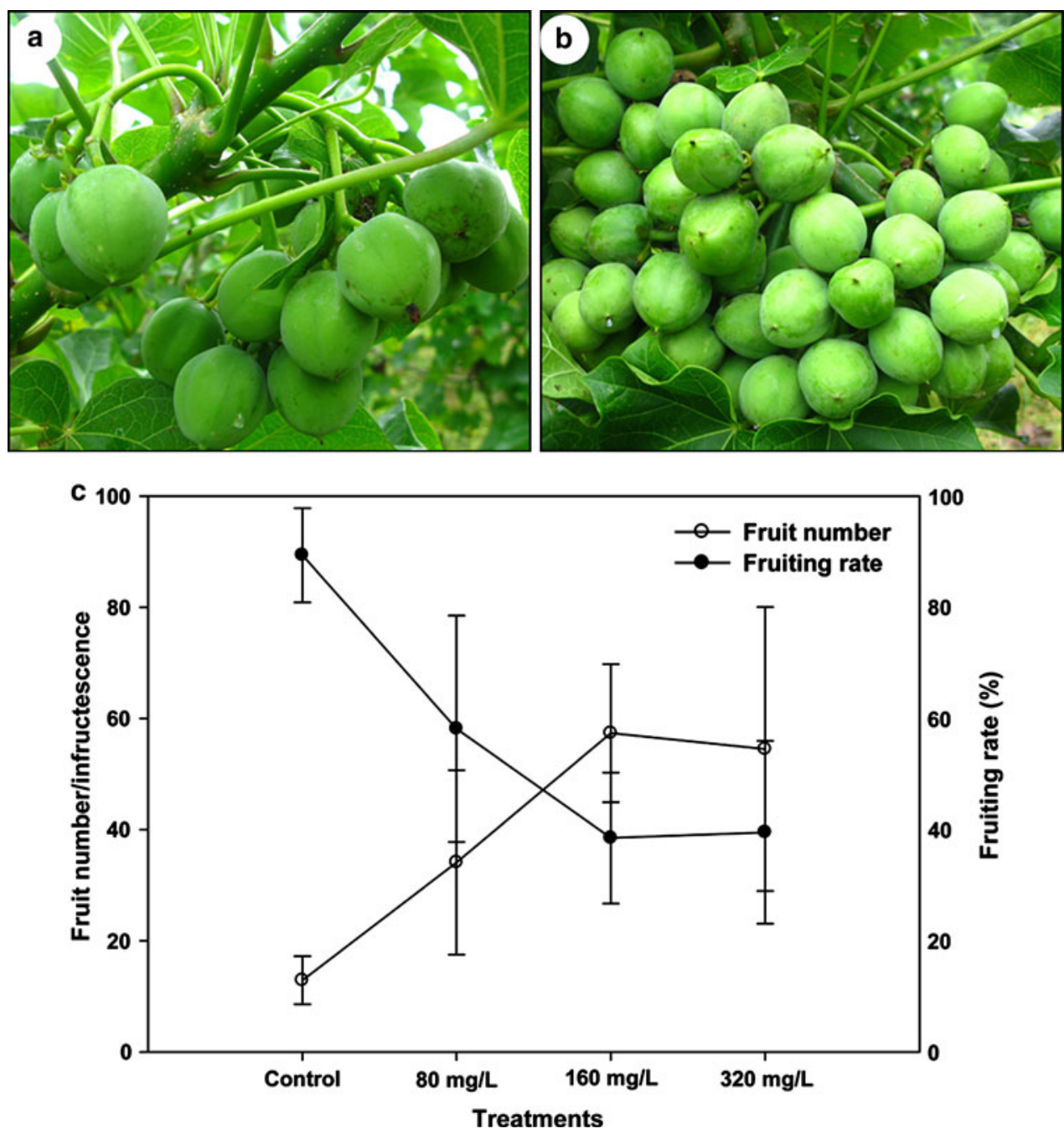

Table 2 Effects of BA treatments on fruit and seed characteristics and oil content of Jatropha

\begin{tabular}{llllll}
\hline BA treatments & Fruits/infructescence & Seeds/fruit & Weight/seed $(\mathrm{g})$ & Seed yield/infructescence $(\mathrm{g})$ & Oil content $(\%)$ \\
\hline Control & $12.92 \pm 4.33$ & $2.42 \pm 0.38$ & $0.77 \pm 0.08$ & $24.10 \pm 10.14$ & $31.67 \pm 2.92$ \\
$80 \mathrm{mg} / 1$ & $32.88 \pm 17.15^{* *}$ & $2.25 \pm 0.34$ & $0.64 \pm 0.10^{* *}$ & $43.22 \pm 23.82^{*}$ & $32.51 \pm 3.09$ \\
$160 \mathrm{mg} / \mathrm{l}$ & $58.04 \pm 12.09^{* *}$ & $2.34 \pm 0.99$ & $0.64 \pm 0.03^{* *}$ & $78.58 \pm 16.41^{* *}$ & $34.76 \pm 1.46^{* *}$ \\
$320 \mathrm{mg} / 1$ & $54.04 \pm 25.94 * *$ & $2.04 \pm 0.44$ & $0.67 \pm 0.06^{* *}$ & $68.23 \pm 35.44^{* *}$ & $32.13 \pm 2.54$ \\
\hline
\end{tabular}

Values are mean \pm standard deviation ( $n=30$ inflorescences)

* Statistically different from the control at $5 \%$ level

** Statistically different from the control at $1 \%$ level

(Ashikari and others 2005). On the other hand, a loss-offunction mutation of the rice LONELY GUY (LOG) gene encoding a CK-activating enzyme that works in the final step of bioactive cytokinin synthesis resulted in a significant decrease in floral organ numbers (Kurakawa and others 2007). Also, $\mathrm{Li}$ and others (2010) reported that transgenic expression of an Arabidopsis CK biosynthetic enzyme gene (AtIPT4) led to an increase in the number of flowers, which was correlated with enlarged inflorescences and flower meristems.

Another interesting observation in the present study was that the exogenous application of BA resulted in the induction of bisexual flowers and a significantly increased proportion of female flowers of Jatropha. This result is in 

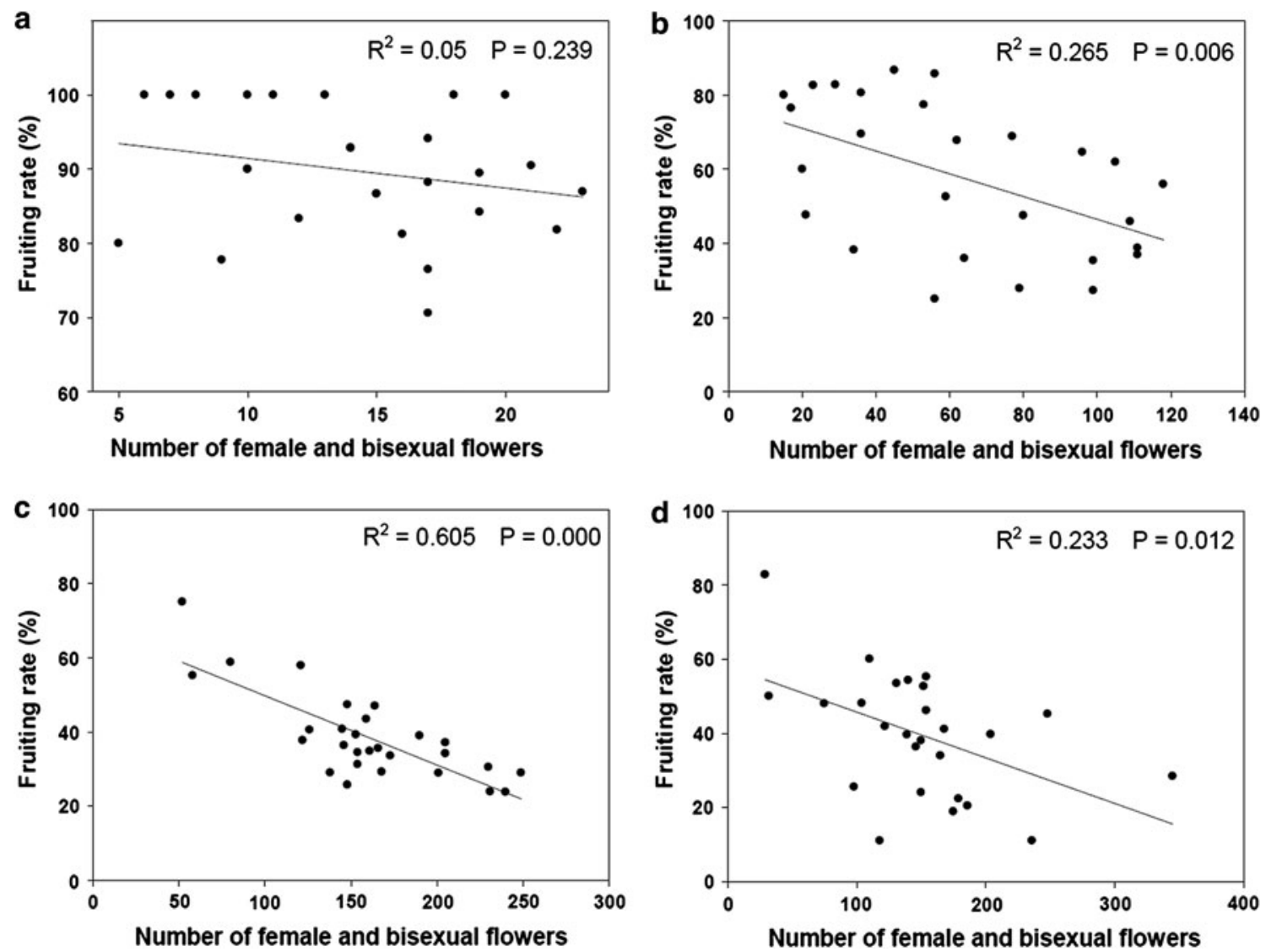

Fig. 4 Linear regression of fruiting rate versus the number of female and bisexual flowers per inflorescence of Jatropha. a Control. b BA treatment at $80 \mathrm{mg} / \mathrm{l}$. c BA treatment at $160 \mathrm{mg} / \mathrm{l}$. d BA treatment at $320 \mathrm{mg} / \mathrm{l}$

line with the previous observations in other plant species. Negi and Olmo $(1966,1972)$ showed that application of a synthetic cytokinin [6-(benzylamino)-9-(2-tetrahydropyranyl)- 9H-purine, PBA] to flower clusters of a male grapevine completely converted the flower sex from male to bisexual (hermaphrodite). Takahashi and others (1980) found that direct application of BA to the staminate inflorescence induced bisexual and pistillate flowers in Luffa cylindrica. In addition, BA was also found to promote the formation of female flowers in Momordica charantia (Ghosh and Basu 1982) and to induce the lateral female and bisexual strobili in the lower part of new shoots of Japanese red pine (Wakushima and others 1996).

Sex determination in unisexual flowers is a complicated process that is achieved by selectively arresting or aborting pistil or stamen development within a bisexual floral meristem (Lebel-Hardenack and Grant 1997; Tanurdzic and Banks 2004; Irish 2005; Liu and others 2008). A number of studies have shown that phytohormones play a pivotal role in the process of the selective arrest or abortion of pistils or stamens in female and male flowers, respectively (Khryanin 2002; Irish 2009; Santner and others
2009). The availability of GAs plays an essential role in the expression of feminizing Anl (Anther earl) and D (Dwarf) genes in maize flowers (Dellaporta and Calderon-Urrea 1994; Irish 2005). In cucumber, ethylene is the key hormone involved in sex determination (Yamasaki and others 2003; Wang and others 2010). The expression of two genes, CS-ACS1 and CS-ACS2, encoding the ethylene biosynthetic enzymes (1-aminocyclopropane-1-carboxylic acid synthase), correlated with sexual phenotypes (Trebitsh and others 1997; Yamasaki and others 2001). Recently, Martin and others (2009) proposed an integrated model of sex determination in melon plants in which the andromonoecious gene CmACS-7, encoding an ethylene biosynthesis enzyme (Boualem and others 2008), and the gynoecious gene $C m W I P 1$, encoding a zinc-finger transcription factor, interact to control the development of male, female, and hermaphrodite flowers. The expression of the pistil repressor $C m W I P 1$ causes the arrest of carpel development and the repression of the expression of the stamen repressor $C m A C S$-7, leading to the formation of male flowers. The inactivation of $C m W I P 1$ by promoter hypermethylation, which also indirectly leads to the 
Fig. 5 Normal 3-seed fruit (a) and BA-induced 4-seed fruit (b)

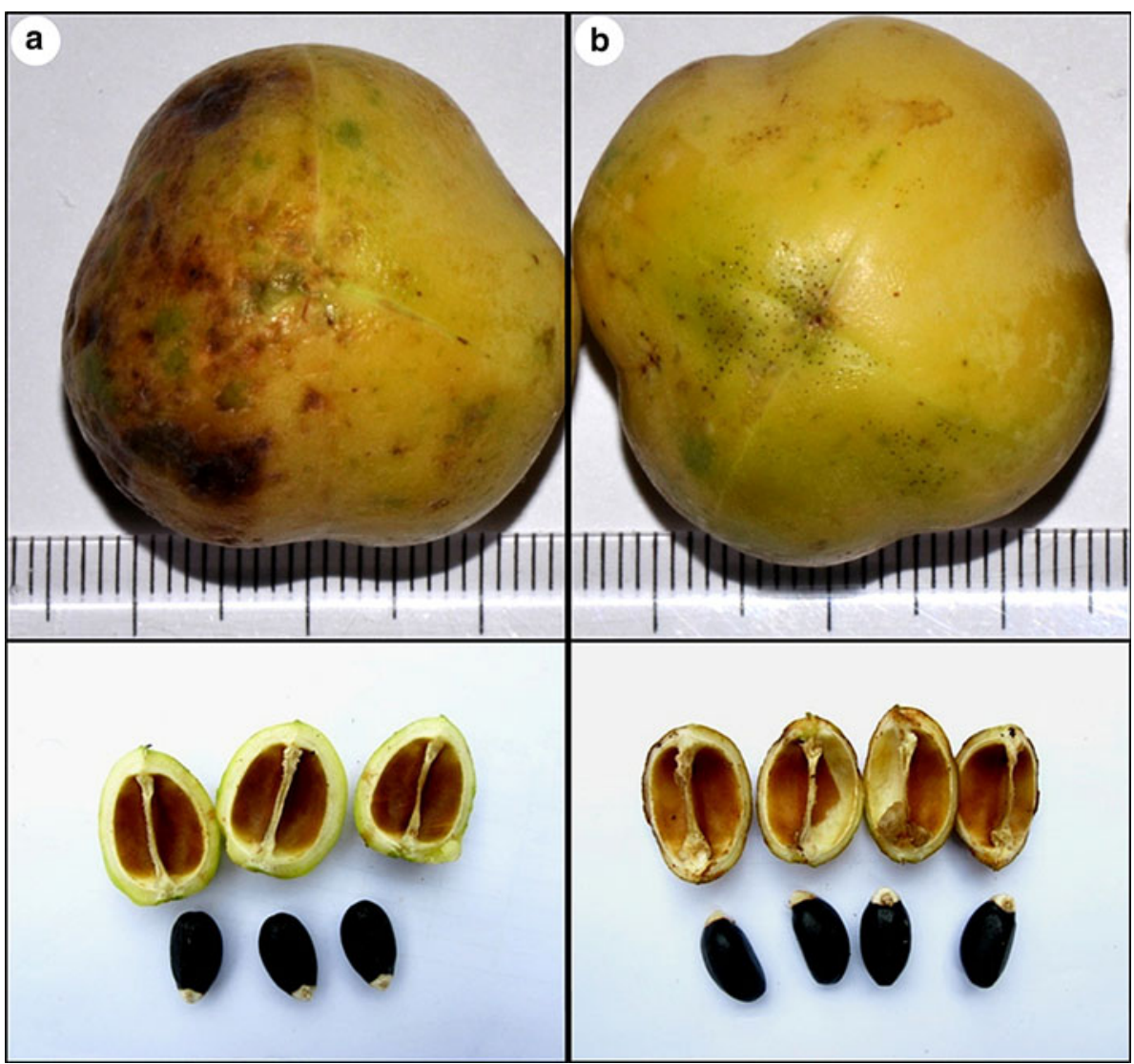

Table 3 Effects of BA treatments on seed size of Jatropha

\begin{tabular}{llll}
\hline BA treatment & Width $(\mathrm{mm})$ & Height $(\mathrm{mm})$ & Length $(\mathrm{mm})$ \\
\hline Control & $8.83 \pm 0.18$ & $11.19 \pm 0.22$ & $18.80 \pm 0.35$ \\
$80 \mathrm{mg} / 1$ & $8.59 \pm 0.46^{*}$ & $10.85 \pm 0.34^{* *}$ & $17.54 \pm 0.78^{* *}$ \\
$160 \mathrm{mg} / 1$ & $8.43 \pm 0.20^{* *}$ & $10.80 \pm 0.19^{* *}$ & $17.07 \pm 0.58^{* *}$ \\
$320 \mathrm{mg} / 1$ & $8.79 \pm 0.38$ & $10.95 \pm 0.25^{* *}$ & $17.61 \pm 0.47^{* *}$
\end{tabular}

Nine hundred seeds of each treatment were analyzed in the experiment. Values are mean \pm standard deviation

* Statistically different from the control at 5\% level

** Statistically different from the control at $1 \%$ level

activation of $C m A C S-7$, permits the development of female flowers. Hermaphrodite flowers resulted from $\mathrm{CmWIPI}$ repression and the presence of a nonfunctional $\mathrm{CmACS}-7$ gene (Boualem and others 2008; Martin and others 2009). These results demonstrated that genes encoding metabolic enzymes for different phytohormones and the related transcription factors play important roles in the sex determination of various plant species.

In contrast to a 3.3-fold increase in seed yield of Jatropha by BA treatment at $160 \mathrm{mg} / \mathrm{l}$ in this study (Table 2), the higher concentration of BA at 3-12 mM (equivalent to $676-2703 \mathrm{mg} / \mathrm{l}$ ) was not much more effective compared to the untreated control (Abdelgadir and others 2009, 2010). These results suggest the critical importance of the concentration of BA in the improvement of seed yield of Jatropha. Because the significant effects of BA treatments on seed yield of Jatropha reported here were at the level of inflorescences, and the effects may not be significant due to the possible autoregulation of the allocation of photosynthetic products at the levels of trees and/or hectares, we are currently investigating the effectiveness of BA treatments at these levels. Preliminary data showed that there was more than a threefold increase in seed yield per Jatropha tree (data not shown). Further studies are necessary to provide direct evidence of the important roles for endogenous CKs in the floral development and sex determination of Jatropha, based on which genes encoding key enzymes in CK metabolism (Zhao 2008; Werner and Schmulling 2009; Kudo and others 2010) in Jatropha could be cloned and used for metabolic engineering of CK in Jatropha inflorescence meristem (Ma 2008; Kiba and Sakakibara 2010). Recently, Ghosh and others (2010) also found an unexpected 5- to 11-fold increase in Jatropha seed yield in the year following a soil application of paclobutrazol, a biosynthesis inhibitor of the plant hormone gibberellin. These studies indicate great potential for improvement in Jatropha seed yield by the application of plant growth regulators, and further genetic improvements through traditional breeding techniques and 
molecular approaches may be possible (Divakara and others 2010). In addition, other PGRs may also be explored to induce synchronous flowering and fruit maturation (Luckwill 1977; Bonnetmasimbert and Zaerr 1987; Santner and others 2009), which may facilitate mechanical harvesting of Jatropha fruits (Carels 2009; King and others 2009).

Acknowledgments We acknowledge Mr. Maosheng Chen for help in designing the experiment; Dr. Jin Chen for great support; and Jingxue Pi, Jun Ni, Mingyong Tang, and Zhiyu Pu for help in the field. This work was supported by the Knowledge Innovation Programs of the Chinese Academy of Sciences (grant Nos. KSCX2-YWZ-0723, KSCX2-YW-G-027, and KSCX2-YW-G-035-1) and the Top Science and Technology Talents Scheme of Yunnan province (grant No. 2009CI123).

Open Access This article is distributed under the terms of the Creative Commons Attribution Noncommercial License which permits any noncommercial use, distribution, and reproduction in any medium, provided the original author(s) and source are credited.

\section{References}

Abdelgadir H, Johnson S, Van Staden J (2009) Effect of foliar application of plant growth regulators on flowering and fruit set in Jatropha curcas - a potential oil seed crop for biodiesel. S Afr J Bot 75:391

Abdelgadir HA, Jager AK, Johnson SD, Van Staden J (2010) Influence of plant growth regulators on flowering, fruiting, seed oil content, and oil quality of Jatropha curcas. S Afr J Bot 76:440-446

Ashikari M, Sakakibara H, Lin SY, Yamamoto T, Takashi T, Nishimura A, Angeles ER, Qian Q, Kitano H, Matsuoka M (2005) Cytokinin oxidase regulates rice grain production. Science 309:741-745

Bonnetmasimbert M, Zaerr JB (1987) The role of plant-growth regulators in promotion of flowering. Plant Growth Regul 6:13-35

Bose TK, Nitsch JP (1970) Chemical alteration of sex expression in Luffa acutangula. Physiol Plant 23:201-206

Boualem A, Fergany M, Fernandez R, Troadec C, Martin A, Morin H, Sari MA, Collin F, Flowers JM, Pitrat M, Purugganan MD, Dogimont C, Bendahmane A (2008) A conserved mutation in an ethylene biosynthesis enzyme leads to andromonoecy in melons. Science 321:836-838

Carels N (2009) Jatropha curcas: a review. In: Kader JC, Delseny M (eds) Advances in botanical research. Academic Press, New York, pp 39-86

Chen W (1991) Changes in cytokinins before and during early flower bud differentiation in lychee (Litchi chinensis Sonn.). Plant Physiol 96:1203

Dehgan B, Webster GL (1979) Morphology and infrageneric relationships of the genus Jatropha (Euphorbiaceae). U Calif Publ Bot 74:1-73

Dellaporta SL, Calderon-Urrea A (1994) The sex determination process in maize. Science 266:1501-1505

Divakara BN, Upadhyaya HD, Wani SP, Gowda CLL (2010) Biology and genetic improvement of Jatropha curcas L.: A review. Appl Energy 87:732-742
Fairless D (2007) The little shrub that could-maybe. Nature 449:652-655

Ghosh S, Basu P (1982) Effect of some growth regulators on sex expression of Momordica charantia L. Sci Hortic 17:107-112

Ghosh A, Chikara J, Chaudhary D, Prakash A, Boricha G, Zala A (2010) Paclobutrazol arrests vegetative growth and unveils unexpressed yield potential of Jatropha curcas. J. Plant Growth Regul 29:307-315

Gifford RM, Evans LT (1981) Photosynthesis, carbon partitioning, and yield. Annu Rev Plant Physiol Plant Mol Biol 32:485-509

Heller J (1996) Physic nut Jatropha curcas L. Promoting the conservation and use of underutilized and neglected crops. 1. Gatersleben: Institute of Plant Genetics and Crop Plant Research. International Plant Genetic Resources Institute, Rome

Irish E (2005) Regulation of sex determination in maize. Bioessays 18:363-369

Irish V (2009) The flowering of Arabidopsis flower development. Plant J 61:1014-1028

Jongschaap R, Corré W, Bindraban P, Brandenburg W (2007) Claims and facts on Jatropha curcas L. Global Jatropha curcas evaluation, breeding and propagation programme. Report 158. Plant Research International BV, Wageningen, the Netherlands

Kandpal JB, Madan M (1995) Jatropha curcus - a renewable source of energy for meeting future energy needs. Renew Energ 6:159-160

Khryanin VN (2002) Role of phytohormones in sex differentiation in plants. Russ J Plant Physiol 49:545-551

Khryanin VN (2007) Evolution of the pathways of sex differentiation in plants. Russ J Plant Physiol 54:845-852

Kiba T, Sakakibara H (2010) Role of cytokinin in the regulation of plant development. In: Pua EC, Davey MR (eds) Plant developmental biology-biotechnological perspectives. Springer, New York, pp 237-254

King AJ, He W, Cuevas JA, Freudenberger M, Ramiaramanana D, Graham IA (2009) Potential of Jatropha curcas as a source of renewable oil and animal feed. J Exp Bot 60:2897-2905

Krizek B, Fletcher J (2005) Molecular mechanisms of flower development: an armchair guide. Nat Rev Genet 6:688-698

Kudo T, Kiba T, Sakakibara H (2010) Metabolism and long-distance translocation of cytokinins. J Integr Plant Biol 52:53-60

Kumar A, Sharma S (2008) An evaluation of multipurpose oil seed crop for industrial uses (Jatropha curcas L.): a review. Ind Crop Prod 28:1-10

Kurakawa T, Ueda N, Maekawa M, Kobayashi K, Kojima M, Nagato Y, Sakakibara H, Kyozuka J (2007) Direct control of shoot meristem activity by a cytokinin-activating enzyme. Nature 445:652-655

Lebel-Hardenack S, Grant SR (1997) Genetics of sex determination in flowering plants. Trends Plant Sci 2:130-136

Li X, Su Y, Zhao X, Li W, Gao X, Zhang X (2010) Cytokinin overproduction-caused alteration of flower development is partially mediated by CUC2 and CUC3 in Arabidopsis. Gene 450:109-120

Liu H, Deng Y, Liao J (2008) Floral organogenesis of three species of Jatropha (Euphorbiaceae). J Syst Evol 46:53-61

Luckwill LC (1977) Growth regulators in flowering and fruit development. In: Plimmer JR (ed) Pesticide chemistry in the 20th Century, ACS Symp Ser 37. American Chemical Society, Washington, DC, pp 293-304

Ma Q (2008) Genetic engineering of cytokinins and their application to agriculture. Crit Rev Biotechnol 28:213-232

Makkar HRS, Becker K (2009) Jatropha curcas, a promising crop for the generation of biodiesel and value-added coproducts. Eur J Lipid Sci Technol 111:773-787

Makkar H, Martínez-Herrera J, Becker K (2008) Variations in seed number per fruit, seed physical parameters and contents of oil, 
protein and phorbol ester in toxic and non-toxic genotypes of Jatropha curcas. J Plant Sci 3:260-265

Martin A, Troadec C, Boualem A, Rajab M, Fernandez R, Morin H, Pitrat M, Dogimont C, Bendahmane A (2009) A transposoninduced epigenetic change leads to sex determination in melon. Nature 461:1135-1138

Negi S, Olmo H (1966) Sex conversion in a male Vitis vinifera L. by a kinin. Sciences 152:1624-1625

Negi SS, Olmo HP (1972) Certain embryological and biochemical aspects of cytokinin SD 8339 in converting sex of a male Vitis vinifera (Sylvestris). Am J Bot 59:851-857

Ohkawa K (1979) Effects of gibberellins and benzyladenine on dormancy and flowering of Lilium speciosum. Sci Hortic $10: 255-260$

Prat L, Botti C, Fichet T (2008) Effect of plant growth regulators on floral differentiation and seed production in Jojoba (Simmondsia chinensis (Link) Schneider). Ind Crop Prod 27:44-49

Raju AJS, Ezradanam V (2002) Pollination ecology and fruiting behaviour in a monoecious species, Jatropha curcas L. (Euphorbiaceae). Curr Sci 83:1395-1398

Rao G, Korwar G, Shanker A, Ramakrishna Y (2008) Genetic associations, variability and diversity in seed characters, growth, reproductive phenology and yield in Jatropha curcas (L.) accessions. Trees-Struct Funct 22:697-709

Ravetta D, Palzkill D (1992) The effect of growth regulators and apex removal on branching and flower bud production of jojoba. Ind Crop Prod 1:47-55

Sanderson K (2009) Wonder weed plans fail to flourish. Nature 461:328-329

Santner A, Calderon-Villalobos LIA, Estelle M (2009) Plant hormones are versatile chemical regulators of plant growth. Nat Chem Biol 5:301-307

Srinivasan C, Mullins M (1978) Control of flowering in the grapevine (Vitis vinifera L.): formation of inflorescences in vitro by isolated tendrils. Plant Physiol 61:127-130

Srinivasan C, Mullins M (1979) Flowering in Vitis: conversion of tendrils into inflorescences and bunches of grapes. Planta 145:187-192

Sunil N, Varaprasad KS, Sivaraj N, Kumar TS, Abraham B, Prasad RBN (2008) Assessing Jatropha curcas L. germplasm in-situ-a case study. Biomass Bioenerg 32:198-202

Sutherland S (1986) Floral sex ratios, fruit-set, and resource allocation in plants. Ecology 67:991-1001
Takahashi H, Suge H, Saito T (1980) Sex expression as affected by $\mathrm{N}^{6}$-benzylaminopurine in staminate inflorescence of Luffa cylindrica. Plant Cell Physiol 21:525-536

Tanurdzic M, Banks J (2004) Sex-determining mechanisms in land plants. Plant Cell Online 16:S61

Tewari JP, Dwivedi HD, Pathak M, Srivastava SK (2007) Incidence of a mosaic disease in Jatropha curcas L. from eastern Uttar Pradesh. Curr Sci 93:1048-1049

Trebitsh T, Staub JE, O'Neill SD (1997) Identification of a 1-aminocyclopropane-1-carboxylic acid synthase gene linked to the female $(\mathrm{F})$ locus that enhances female sex expression in cucumber. Plant Physiol 113:987-995

Wakushima S, Yoshioka H, Sakurai N (1996) Lateral female strobili production in a Japanese red pine (Pinus densiflora Sieb. Et Zucc.) clone by exogenous cytokinin application. J Forest Res 1:143-148

Wang YH, Li JY (2008) Molecular basis of plant architecture. Annu Rev Plant Biol 59:253-279

Wang DH, Li F, Duan QH, Han T, Xu ZH, Bai SN (2010) Ethylene perception is involved in female cucumber flower development. Plant J 61:862-872

Werner T, Schmulling T (2009) Cytokinin action in plant development. Curr Opin Plant Biol 12:527-538

Werner T, Motyka V, Strnad M, Schmlulling T (2001) Regulation of plant growth by cytokinin. Proc Natl Acad Sci USA 98:10487-10492

Werner T, Motyka V, Laucou V, Smets R, Van Onckelen H, Schmulling T (2003) Cytokinin-deficient transgenic Arabidopsis plants show multiple developmental alterations indicating opposite functions of cytokinins in the regulation of shoot and root meristem activity. Plant Cell 15:2532

Xiong G, Li J, Wang Y (2009) Advances in the regulation and crosstalks of phytohormones. Chinese Sci Bull 54:2718-2733

Yamasaki S, Fujii N, Matsuura S, Mizusawa H, Takahashi H (2001) The $\mathrm{M}$ locus and ethylene-controlled sex determination in andromonoecious cucumber plants. Plant Cell Physiol 42:608-619

Yamasaki S, Fujii N, Takahashi H (2003) Characterization of ethylene effects on sex determination in cucumber plants. Sex Plant Reprod 16:103-111

Zhao Y (2008) The role of local biosynthesis of auxin and cytokinin in plant development. Curr Opin Plant Biol 11:16-22 